\title{
LOXIA JUGULARIS.
}

- 0

\section{CHARAOTER GENERICUS.}

Rofrum conico-gibbum, frontis bafi rotundatum verfus caput: Mandibula inferior margine laterali inflexa.

Nares in bafi roltri.

Isingua integra.

Lin. Syf. Nat.p. 299.

CHARACTER SPECIFICUS.

LOXIA teftaceo-ferruginea, nigro undulata, fafcia gulæ fanguinea.

Africam incolit hæc avicula. Coloris eft Caftanei; feu grifeo-ferruginei, maculis lunatis nigris eleganter undulati : Decoratur gula fafcia lata tranfverfa vivide coccinea. 


\section{RED-THROATED GROSSBEAK.}

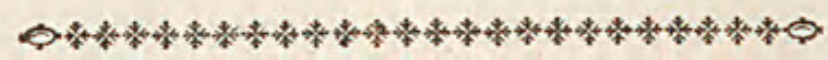

GENERIC CHARACTER.

Bill ftrong, thick, and convex.

Noftrils fmall.

Tongue truncated.

SPECIFIC CHARACTER, EेC.

PALE-FERRUGINOUS LOXIA, undulated with black, with a blood-red fafcia on the throat.

FASCIATED GROSSBEAK.

Lath. Synopf. 2. p. 156

THE CUT-THROAT SPARROW.

Lev. $M u$ S.

This bird is a native of Africa. Its colour is a palifh chefnut, or grey ferruginous, elegantly undulated with femi-lunar marks of black. The throat is ornamented with a broad tranfverfe band of the deepeft vivid red. 


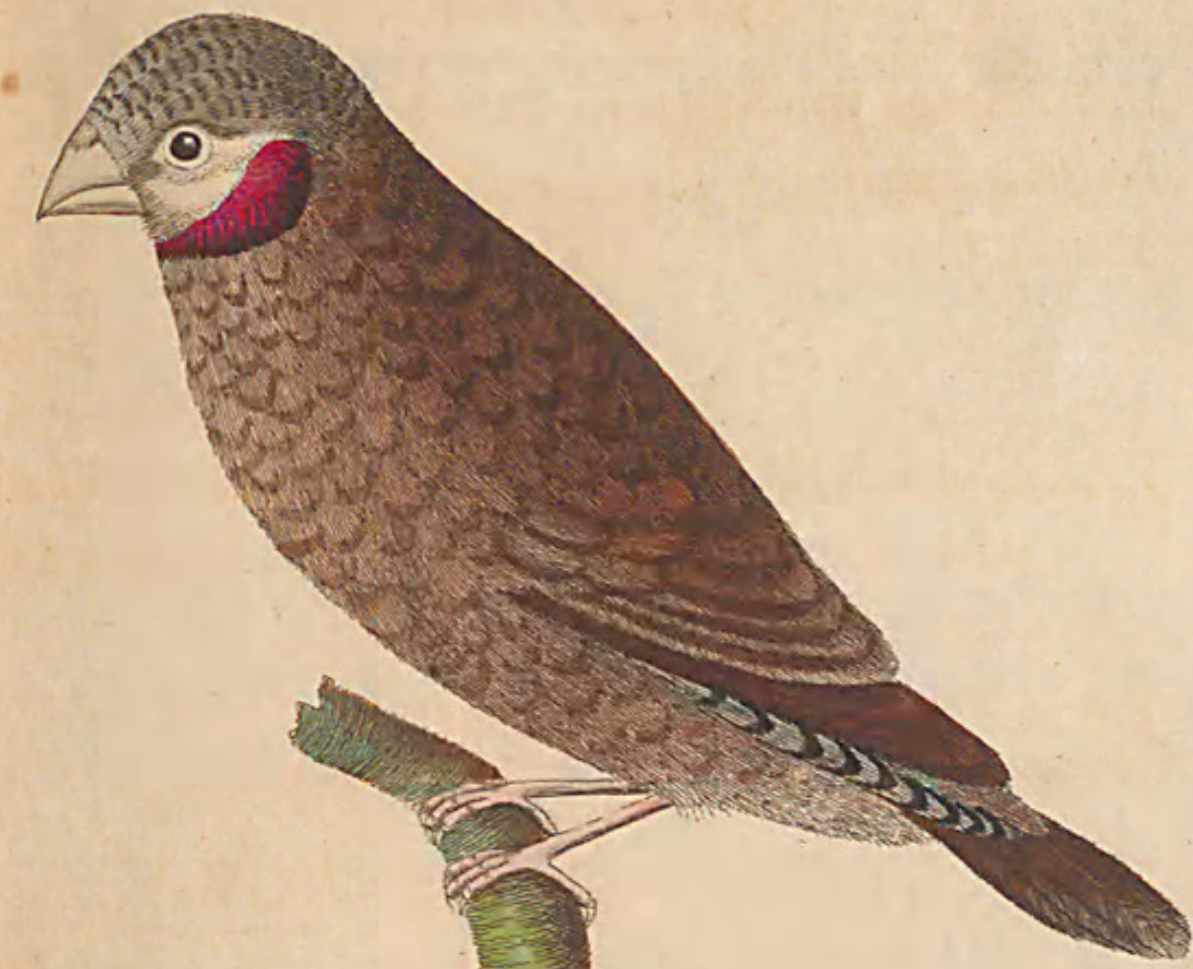




\section{$2 \mathrm{BHL}$ Biodiversity Heritage Library}

Shaw, George. 1790. "The Red-Throated Grossbeak, Loxia jugularis [PI. 56]." The Naturalist's Miscellany 2(XV), https://doi.org/10.5962/p.310708.

View This Item Online: https://www.biodiversitylibrary.org/item/276232

DOI: https://doi.org/10.5962/p.310708

Permalink: https://www.biodiversitylibrary.org/partpdf/310708

\section{Holding Institution}

Museums Victoria

\section{Sponsored by}

Atlas of Living Australia

\section{Copyright \& Reuse}

Copyright Status: Public domain. The BHL considers that this work is no longer under copyright protection.

This document was created from content at the Biodiversity Heritage Library, the world's largest open access digital library for biodiversity literature and archives. Visit BHL at https://www.biodiversitylibrary.org. 